\title{
The Involvement of Neuroinflammation in Dengue Viral Disease: Importance of Innate and Adaptive Immunity
}

\author{
Rituraj Niranjan Subramanian Muthukumaravel Purushothaman Jambulingam \\ Unit of Microbiology and Molecular Biology, ICMR-Vector Control Research Center, Puducherry, India
}

\section{Keywords \\ Dengue fever · Natural killer cells · Neuroinflammation . \\ Encephalitis $\cdot$ T cells $\cdot$ Mediators of inflammation}

\begin{abstract}
Neuroinflammation (inflammation in brain) has been known to play an important role in the development of dengue virus disease. Recently, studies from both clinical and experimental models suggest the involvement of neuroinflammation in dengue viral disease. Studies in clinical setup demonstrated that, microglial cells are actively involved in the patients having dengue virus infection, showing involvement of innate immune response in neuroinflammation. It was further proved that, clinical isolates of dengue- 2 virus were able to initiate the pathologic response when injected in the mice brain. Natural killer cells were also found to play a crucial role to activate adaptive immune response. Notably, CXCL10/IFN-inducible protein 10 and CXCR3 are involved in dengue virus-mediated pathogenesis and play an important role in the development of dengue virus-mediated paralysis. In a latest report, it was seen that intracranial injection of dengue virus increases the $\mathrm{CD} 8^{+} \mathrm{T}$-cell infiltration in brain, showing an important mechanism of neuroinflammation during the dengue virus infection. A similar
\end{abstract}

study has described that, when DENV-3 is injected into the mice, it enhances the infiltration of $\mathrm{CD}^{+}$and $\mathrm{CD} 4^{+} \mathrm{T}$ cells as well as neutrophils. Cells immune-reactive against NS3 antigen were found throughout the brain. In conclusion, we focus on the various molecular mechanisms which contribute to the basic understanding about the role of neuroinflammation in dengue fever. These mechanisms will help in better understanding dengue pathophysiology and thus help in the development of possible therapeutics.

(C) 2019 S. Karger AG, Basel

\section{Introduction}

In the recent decades, dengue virus infection has become a major health problem globally. There are generally four main types of dengue virus serotypes $[1,2]$. Dengue infections in general are caused to the host by Aedes aegypti and Aedes albopictus mosquitoes [3, 4]. Dengue virus comes under the flaviviridae family and is very similar to yellow fever, Japanese encephalitis virus, and St. Louis and West Nile viruses [5]. In fact, infection from one kind of serotype allowing patients a lifelong protection from the same or homologous serotype is no longer true [6]. It is important to note that this protection is not a pro-

\section{KARGER}

(c) 2019 S. Karger AG, Basel

E-Mail karger@karger.com

www.karger.com/nim
Dr. Rituraj Niranjan, Scientist-C, Talent Search Scientist (TSS-ICMR)

Unit of Microbiology and Molecular Biology

ICMR-Vector Control Research Center

Puducherry 605006 (India)

E-Mail riturajniranjan@ rediffmail.com 
tection from other serotypes [7]. The second-time infection with the other serotype of the primary infection results in very severe complications $[8,9]$. In fact, antibodies generated in the primary infection lead towards severe complication in the secondary infections [10]. The progress in the development of the vaccine has been unsuccessful only due to the limited knowledge of the immune response against dengue virus [10]. Dengue virus envelop is basically made up of lipid and contains a single-positive stranded RNA as a genome $[11,12]$. The dengue gene encodes a big protein precursor of approximately 3,400 amino acids long. This big precursor protein is subsequently post-translationally modified by virus-encoded protease NS2B/NS3 and host cell signalases to produce seven nonstructural and three structural proteins [13]. These three structural proteins, core, pre-membrane, and envelope are involved in the virus particle assembly, while seven non-structural proteins, i.e., NS1 to NS5, are believed to play an important role in the viral RNA replication and host immune responses [12]. It is now accepted that immune system is activated by these nonstructural virus particles that play an important role in the development of neuroinflammation in dengue fever [12].

The traditional classification of the World Health Organization (WHO) of dengue fever is still practiced, which includes two major parts, the dengue fever and dengue hemorrhagic fever/dengue shock syndrome [14]. Recent studies have suggested that these play a huge role in inflammation-associated neurodegeneration [15]. It was evident that pro-inflammatory cytokines and chemokines were elevated in dengue fever patients [16]. The mediators of inflammation were found upregulated with severe dengue disease [16]. Therefore, it can be speculated that peripheral inflammation might be initiating the inflammatory cascade in the brain and be responsible for inflammation-associated responses.

Dengue virus is generally considered a non-neurotrophic virus pathogen; however, some scientists have found it in brain fluids and dengue antigen in brain tissue [17]. It is now considered that dengue infection should be responsible for the initiation and progression of the inflammation in brain [17]. Recently, dengue virus is associated with encephalitis and various kinds of neuropathies [18]. Therefore, nowadays the dengue infection has been considered as one of the causes of encephalitis [19]. It is further interesting to note that patients showing dengue mediated inflammation exhibited various signs like intermittent tremors, convulsions stiffness in neck, altered consciousness, and sometimes coma. It is now considered that different kinds of virus antigens are involved in the dengue pathogenesis, which initiate and progress the disease [20]. The key component involved in the mechanism of neuroinflammation in dengue patients therefore need a systemic review [21].

\section{The Evidence for the Involvement of Neuroinflammation in Dengue Virus Disease}

Neuroinflammation is an inflammatory mechanism of brain and is involved in many vector-borne diseases [22, 23]. A vast variety of clinical, experimental studies demonstrate that there is a clear-cut role of neuroinflammation in dengue virus infections. Many clinical observations suggest the involvement of neuroinflammation in dengue viral disease (Fig. 1). Some manifestations in central nervous systems were also found in the dengue patients [24]. In a report of young patients diagnosed with dengue encephalitis, it was observed that there is involvement of central nervous system [25]. There were also more cases of neurological symptoms which were reported in the severe dengue cases [26]. The disseminated encephalomyelitis in acute form has also been reported in the dengue hemorrhagic fever conditions $[27,28]$. In a report, it was also observed that there is opsoclonus-myoclonus-ataxia syndrome, which was believed to be in dengue patients [29]. Acute polyneuritis has been associated with the dengue infection [30]. A study on the pediatric cases reported that there is linkage in the persistent infection in the brain and neuroinflammation as a key neurological manifestation [31]. The activation of brain microglial cells is an important mechanism seen during the neuroinflammatory process. It is important to note that microglial activation was seen in the case of dengue infection of central nervous system [32]. Interestingly, there has been a presence of effector-memory $\mathrm{CD}^{+} \mathrm{T}$ cells inside the central nervous system of dengue patients who were diagnosed with dengue virus encephalitis [33]. There have been many reported cases of encephalitis in the dengue cases [34]. In a recent study, "cerebral venous thrombosis" presentation was observed, which is considered to be an unusual presentation of pathogenesis [35]. When dengue disease is enhanced by the antibody, it generates a profound neuroinflammatory response [36]. On day one of dengue infection, it can lead to the development of encephalitis [37, 38]. A recent case report from Pakistan has also published an acute encephalopathy due to dengue infection [39]. There have also been cases with cross-reactive IgM responses in dengue patients with other diseases. Therefore, a particular diagnosis is important in the diagnosis of dengue [40]. In case of dual 


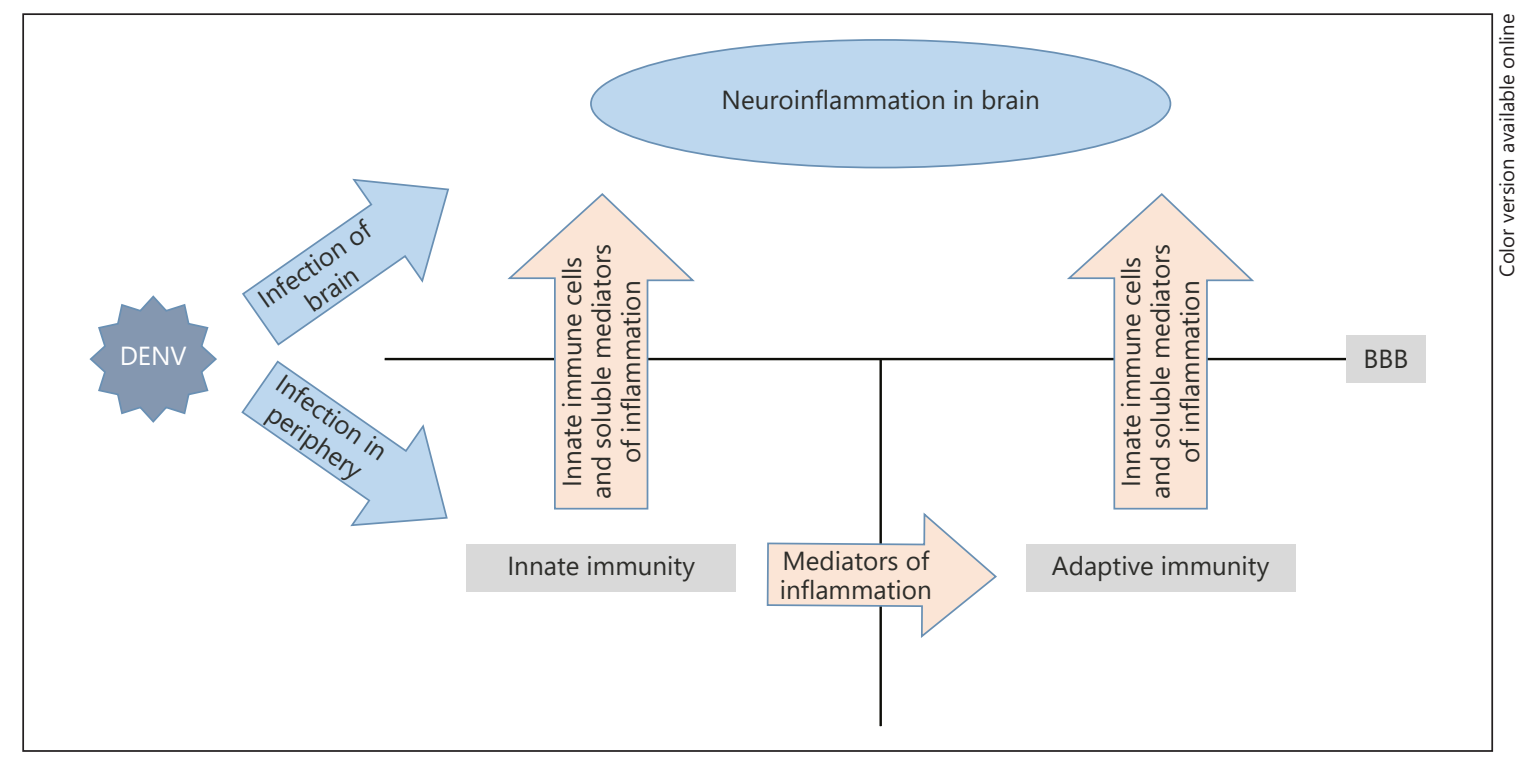

Fig. 1. Schematic representation of involvement of neuroinflammation in dengue virus infection. Lower panel shows the importance of innate and adaptive immune system in the initiation and progression of neuroinflammation.

infection with malaria, dengue patients show some special kind of clinical manifestations [41].

A significant amount of evidence from experimental models confirmed the involvement of neuroinflammation in dengue viral disease. Viral infections can rupture the blood brain barrier and allows immune cells to pass to the brain $[42,43]$. The fact that systemic inflammation is involved in the dengue virus encephalopathy comes from intratracheal infection of dengue virus in mice [44]. The dengue virus-3 infected mice model shows higher levels of anxiety in comparison with controls [45]. It was demonstrated that CXCL10/IFN-inducible protein 10 and CXCR3 are involved in the dengue virus-mediated pathogenesis and play an important role in the development of dengue virus-mediated paralysis [46]. Combined immune-deficient mice also showed the symptoms of paralysis due to dengue virus, showing the involvement of immune system [47]. It has now been clearly indicated that there is a huge role of microglia-mediated neuroinflammation in the dengue cases [48]. Vaccination study in mice showed that a tetravalent vaccine candidate protects from dengue virus-mediated virus encephalitis [49]. It was further proved that clinical isolates of dengue- 2 virus were able to initiate the pathologic response in brain [50]. Microglia were found to be protective in dengue virus-induced encephalitis in a mice model [48]. It was further confirmed using dengue virus isolates in $\mathrm{BALB} / \mathrm{c}$ mice that dengue hemorrhagic fever can be clearly distinguished from dengue shock syndrome [51]. Recently, a tetravalent vaccine study in mice showed some promising results and suggested its use as a potential drug candidate in future against dengue virus infection [49]. It was also seen that a dengue virus isolate and its proteins cause death of human microvascular endothelial cells, which indicates its relevance to the pathogenesis [52]. Some inhibitory strategies also indirectly support the involvement of neuroinflammation in dengue viral disease. In line of this, many strategies have been established like heat shock factor-1, which can be a good antiviral tool to combat the dengue virus infection [53]. Human heme oxygenase-1 was associated to be an important host cell factor against dengue virus replication [54]. Another dual miRNA targeting was also found to be suitable for the restriction of host range that attenuates dengue virus virulence in brain [55].

\section{The Role of Innate Immune Response in the Development of Neuroinflammation in Dengue Viral Disease}

Numerous lines of evidence support the involvement of innate immune response in dengue pathogenesis [56, 57]. It was long back speculated that innate immune cells of the body keep a check and neutralize dengue virus before it reaches the different parts of the body $[58,59]$. In this area, mainly macrophages and monocytes were con- 
sidered, which is also supported by the latest evidence [60]. Nowadays, other cells and mediators of the immune system are found to be responsible in the development or activation of innate immune response and thus subsequently neuroinflammation $[32,61]$. Recently, natural killer cells are gaining much more importance in dengue viral disease due to their vast variety of functions and advancement in their importance in the regulation of innate and adaptive immune system. The natural killer cells are tremendously involved in the pathogenesis of dengue virus disease by showing their early activation [62]. Moreover, natural killer cells also keep check on the dengueinfected cells of the body and destroy them at their earliest infection [63]. The endothelial cells, when becoming infected with the dengue infection, significantly stimulate the activation of innate immune response $[64,65]$. The altered level of toll-like receptor expression was also observed during the dengue virus infections [66]. The invasion of innate immune response was found to be accomplished by the methylation $[67,68]$. However, it is now confirmed that nonstructural proteins of the dengue virus are responsible for invading the innate immune response [69]. In line of this, mast cells and neutrophils also seem to be responsible for the innate immune reactions and development of devastating pathogenesis [70, 71]. Reports also point out that there is clear-cut role of mast cells in the development of dengue pathogenesis [72]. A recent study from mice shown that the effect of NS1 is mediated by the mast cell response and thus the severity of the dengue infection [73]. It was also understood that dengue infection causes severe complications in the brain, as observed in the twin case [74].

\section{The Role of Adaptive Immune Response in the Development of Neuroinflammation in Dengue Viral Disease}

Apart from innate immune response, dengue virus infection causes adaptive immune response [75, 76]. Evidence from different clinical and experimental models now support that, there is clear-cut involvement of adaptive immune response in the development of neuroinflammation-associated pathophysiology in dengue viral disease $[75,77]$. It was observed that, levels of IL- 4 and -10 in patient's serum were significantly increased in severe dengue cases. However, serum IL-2 levels were found unaffected along with the severity of cases $[78,79]$. Recently, $\mathrm{Ab}-$ Rahman et al. [80] suggested that sCD163 can be used as a biomarker to identify the severe dengue cases from the normal dengue cases [80]. A vital information came from dengue dead patients where hemophagocytic syndrome inside bone marrow was the key component responsible for death [81]. When DENV-2 strain 66985 was injected in $\mathrm{BALB} / \mathrm{c}$ mice by intravenous route, a severe form of insult is observed in the central nervous system [82]. In a latest study, it was seen that intracranial injection of dengue virus increases $\mathrm{CD}^{+} \mathrm{T}$-cell Infiltration in brain, showing an important mechanism of neuroinflammation during the dengue virus infection [83]. Another similar study described that, when DENV-3 is injected into the mice, it enhances infiltration of $\mathrm{CD}^{+}$and $\mathrm{CD}^{+}{ }^{+} \mathrm{T}$ cells as well as neutrophils. Cells immune-reactive against NS3 antigen were found throughout the brain [44]. Immunereactive cells for anti-dengue were visualized throughout the brain and also altered the behavioral changes that occur before the death of mice [44]. Similarly, in a study, it was found that DENV2 induces encephalitis in mice [50]. Interestingly, it was observed that dengue-specific $\mathrm{CD} 8^{+}$ $\mathrm{T}$ cells play beneficial as well as destructive roles [84]. A detailed study in brain and spinal cord of rhesus monkey (Macaca mulatta) has shown the neuro-virulence mechanisms of dengue- 2 virus [85]. It is now widely believed that Th-17 cells strongly participate in the evasion of blood brain barrier in the severe cases of dengue viral infection and development of neuroinflammation $[42,86]$. While it is important to see that, there is effect of peripheral immune cells to the brain, there is a recent study in mice which shows that brain cells also effect peripheral immune system [87]. Taken together, it can be concluded that there is significant involvement of both innate and adaptive immune system in the neuroinflammation, and brain inflammation is profoundly connected to the peripheral immune system of the body (Fig. 2).

\section{Some Important Aspects That Are Needed to Be Explored in Dengue Virus Disease}

From the above-mentioned studies, it is now believed that, there is a clear-cut role of immune system in the initiation and progression of inflammation in brain $[88,89]$. In this line, various different kinds of immune cells and their mediators need to be explored to understand the pathophysiology of disease [34]. For example, studies suggest that there is a profound involvement of monocytes in dengue pathogenesis, but their exact role is not understood $[90,91]$. Monocytes are cells which are the most infected cells of the body during the dengue virus infections. Here, we highlight the role of monocytes in 


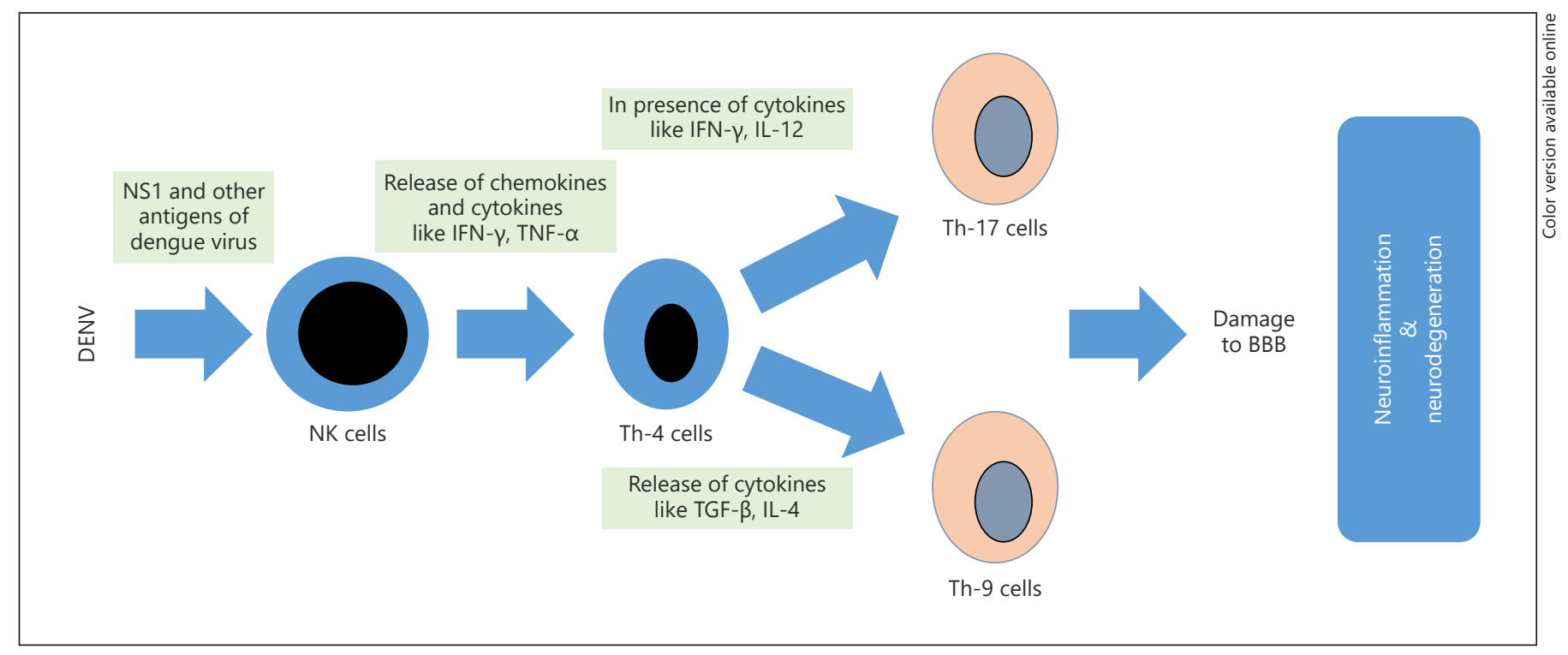

Fig. 2. Proposed mechanism for the involvement of innate and adaptive immune cells in the dengue virus-mediated neuroinflammation. We hereby propose that, first natural killer cells or other cells of the immune system get activated by dengue virus and then, they subsequently activate helper cells. These helper cells devide

this disease, but how they target the neuroinflammation is not yet understood [92]. As we know, the secondary infection in dengue is much more severe than the primary and involves some cells of allergic responses [72]. Therefore, the role of mast cells in this dengue infection has been postulated, but the exact role still needs to be figured out in details [93]. Further, the role of eosinophils needs to be explored in the dengue disease conditions [94]. Moreover, the roles of matrix metalloproteases need to be known in the severe cases of dengue disease [95]. Matrix metalloproteinases are very critical in the development of severe form of dengue pathology specially hemorrhagic conditions and dengue shock syndrome (DSS). We emphasize on exploration of innate immune cells mediated role of matrix metalloproteinases in the plasma leakage associated to Dengue Shock Syndrome as well as in the neuroinflammation.

\section{Conclusion and Future Perspectives}

In this review, we have shown that there is clear involvement of innate immune system and subsequent inflammatory response in the initiation of neuroinflammatory process in the brain $[57,96]$. It is also further assessed that, both kinds of immune response (innate and adap- and get converted into Th-17 and Th- 9 cells, which damage the blood brain barrier and subsequently provide the ways for the other immune cells and their mediators to go to the brain and cause the neuroinflammation.

tive) take part in the initiation and progression of encephalitic pathophysiology of disease. It was seen that intracranial injection of dengue virus increases $\mathrm{CD} 8^{+} \mathrm{T}$-cell infiltration in brain, showing an important mechanism of neuroinflammation during the dengue virus infection. A similar study described that when DENV-3 is injected into the mice, it enhances the infiltration of $\mathrm{CD}^{+}$and $\mathrm{CD}^{+} \mathrm{T}$ cells as well as neutrophils. The immune cells reactive against NS3 antigen of dengue virus were found throughout the brain. Taking all these together, it is now considered that dengue infection involves lots of immunologic mediators which induce the neuroinflammation in brain and may be responsible for the encephalitic death of dengue infected patients. Therefore, future strategies should be developed to understand and manage neuroinflammation in the brain.

\section{Acknowledgements}

The young scientist grant No. SB/YS/LS-198/2014 to Dr. Rituraj Niranjan by SERB (DST, India.) is gratefully acknowledged. Technical help from Vaishnavi Srinivasan is also acknowledged.

\section{Disclosure Statement}

The authors declare that they have no conflict of interests. 


\section{References}

1 Arima Y, Chiew M, Matsui T; Emerging Disease Surveillance and Response Team, Division of Health Security and Emergencies, World Health Organization Regional Office for the Western Pacific. Epidemiological update on the dengue situation in the Western Pacific Region, 2012. Western Pac Surveill Response J. 2015 Apr;6(2):82-9.

2 Arya S, Agarwal N. Dengue and dengue hemorrhagic fever. Aust Fam Physician. 2007 May;36(5):295.

3 Armstrong PM, Rico-Hesse R. Differential susceptibility of Aedes aegypti to infection by the American and Southeast Asian genotypes of dengue type 2 virus. Vector Borne Zoonotic Dis. 2001;1(2):159-68.

4 Arragain L, Dupont-Rouzeyrol M, O’Connor O, Sigur N, Grangeon JP, Huguon E, et al. Vertical Transmission of Dengue Virus in the Peripartum Period and Viral Kinetics in Newborns and Breast Milk: new Data. J Pediatric Infect Dis Soc. 2017 Nov 24;6(4):324-31.

5 Arnaoutakis D, Padhya TA. Dengue fever: a primer for the otolaryngologist. Ear Nose Throat J. 2013 Jul;92(7):E5-9.

6 Artimos de Oliveira S, Rodrigues CV, Camacho LA, Miagostovich MP, Araújo ES, Nogueira RM. Diagnosis of dengue infection by detecting specific immunoglobulin $\mathrm{M}$ antibodies in saliva samples. J Virol Methods. 1999 Jan;77(1):81-6.

7 Arya SC, Agarwal N. Dengue and concurrent urinary infection in a tertiary care hospital in Delhi. Trans R Soc Trop Med Hyg. 2009 Jun 103(6):642-3.

8 Armstrong PM, Andreadis TG, Finan SL Shepard JJ, Thomas MC. Detection of infectious virus from field-collected mosquitoes by vero cell culture assay. J Vis Exp. 2011 Jun;(52):2889.

9 Burnett M. Dengue infections. J Spec Oper Med. 2013;13(2):64-8.

10 Arya SC, Agarwal N. Seroprevalence of dengue virus antibodies in healthy Jamaicans. Hum Antibodies. 2010;19(1):27.

11 Arya SC, Agarwal N, Parikh SC. Detection of dengue NS1 antigen, alongside IgM plus IgG and concurrent platelet enumeration during an outbreak. Asian Pac J Trop Med. 2011 Aug; 4(8):672.

12 Bäck AT, Lundkvist A. Dengue viruses - an overview. Infect Ecol Epidemiol. 2013 Aug;3:

13 Arias CF, Preugschat F, Strauss JH. Dengue 2 virus NS2B and NS3 form a stable complex that can cleave NS3 within the helicase domain. Virology. 1993 Apr;193(2):888-99.

14 Bagcchi S. Number of dengue cases in Delhi is highest for five years. BMJ. 2015 Aug; 351:h4199.

15 Velandia-Romero ML, Acosta-Losada O, Castellanos JE. In vivo infection by a neuroinvasive neurovirulent dengue virus. J Neurovirol. 2012 Oct; 18(5):374-87.
16 Arias J, Valero N, Mosquera J, Montiel M, Reyes E, Larreal Y, et al. Increased expression of cytokines, soluble cytokine receptors, soluble apoptosis ligand and apoptosis in dengue. Virology. 2014 Mar;452-453:42-51.

17 An J, Zhou DS, Kawasaki K, Yasui K. The pathogenesis of spinal cord involvement in dengue virus infection. Virchows Arch. 2003 May;442(5):472-81.

18 Araújo FM, Araújo MS, Nogueira RM, Brilhante RS, Oliveira DN, Rocha MF, et al. Central nervous system involvement in dengue: a study in fatal cases from a dengue endemic area. Neurology. 2012 Mar;78(10):736-42.

19 Arora SK, Aggarwal A, Mittal H. Dengue encephalitis in children. J Neurosci Rural Pract. 2012 May;3(2):228-9.

20 Arroyo V, Moreau R, Kamath PS, Jalan R, Ginès $\mathrm{P}$, Nevens $\mathrm{F}$, et al. Acute-on-chronic liver failure in cirrhosis. Nat Rev Dis Primers. 2016 Jun;2(1):16041.

21 Badreddine S, Al-Dhaheri F, Al-Dabbagh A, Al-Amoudi A, Al-Ammari M, Elatassi N, et al. Dengue fever. Clinical features of 567 consecutive patients admitted to a tertiary care center in Saudi Arabia. Saudi Med J. 2017 Oct; 38(10):1025-33.

22 Raquin V, Valiente Moro C, Saucereau Y, Tran FH, Potier P, Mavingui P. Native Wolbachia from Aedes albopictus Blocks Chikungunya Virus Infection In Cellulo. PLoS One. 2015 Apr;10(4):e0125066.

23 Angibaud G, Luaute J, Laille M, Gaultier C. Brain involvement in Dengue fever. J Clin Neurosci. 2001 Jan;8(1):63-5.

24 Thisyakorn U, Thisyakorn C, Limpitikul W, Nisalak A. Dengue infection with central nervous system manifestations. Southeast Asian J Trop Med Public Health. 1999 Sep;30(3): 504-6.

25 Alice V, Cheong BM. Early central nervous system involvement in a young patient with dengue encephalitis. Med J Malaysia. 2016 Feb;71(1):41-3

26 Strobel M, Lamaury I, Contamin B, Jarrige B, Perez JM, Steck AJ, et al. [Dengue fever with neurologic expression. Three cases in adults]. Ann Med Interne (Paris). 1999 Feb;150(2): 79-82.

27 Sundaram C, Uppin SG, Dakshinamurthy $\mathrm{KV}$, Borgahain R. Acute disseminated encephalomyelitis following dengue hemorrhagic fever. Neurol India. 2010 Jul-Aug; 58(4):599-601.

28 Fragoso YD, Brooks JB. Encephalomyelitis Associated With Dengue Fever. JAMA Neurol. 2016 Nov;73(11): 1368.

29 Tan AH, Linn K, Ramli NM, Hlaing CS, Aye AM, Sam IC, et al. Opsoclonus-myoclonusataxia syndrome associated with dengue virus infection. Parkinsonism Relat Disord. 2014 Nov;20(11):1309-10.
30 Acevedo J, Casanova MF, Antonini AC, Morales $H$. Acute polyneuritis associated with dengue. Lancet. 1982 Jun;1(8285):1357.

31 Aggarwal A, Kumar P, Faridi MM. Neurological manifestation as presenting feature of dengue infection. J Pediatr Neurosci. 2015 Jan-Mar;10(1):76-7.

32 Bhatt RS, Kothari ST, Gohil DJ, D’Souza M, Chowdhary AS. Novel evidence of microglial immune response in impairment of Dengue infection of CNS. Immunobiology. 2015 Oct; 220(10):1170-6.

33 van der Most RG, Murali-Krishna K, Ahmed R. Prolonged presence of effector-memory CD8 T cells in the central nervous system after dengue virus encephalitis. Int Immunol. 2003 Jan;15(1):119-25.

34 Varatharaj A. Encephalitis in the clinical spectrum of dengue infection. Neurol India. 2010 Jul-Aug;58(4):585-91.

35 Vasanthi N, Vairamon PM, Gowtham T, Das AK. Unusual Presentation of Dengue FeverCerebral Venous Thrombosis. J Clin Diagn Res. 2015 Jun;9(6):OD09-10.

36 Feitosa RN, Vallinoto AC, Vasconcelos PF, Azevedo RS, Azevedo VN, Machado LF, et al. Gene Polymorphisms and Serum Levels of Pro- and Anti-Inflammatory Markers in Dengue Viral Infections. Viral Immunol. 2016 Sep;29(7):379-88.

37 Abeywardana S, Peiris PJ, Gunasekara AC, Sinhabahu VP. Dengue haemorrhagic fever in a child presenting as encephalitis on day one of fever. Ceylon Med J. 2012 Dec;57(4):177.

38 Baheti G, Mehta V, Ramchandani M, Ghosh GC: Dengue fever with encephalitis: a rare phenomenon. BMJ Case Rep. 2018. DOI: 10.1136/bcr-2018-225463.

39 Abbas Q, Jafri SK, Ishaque S, Jamil MT. Acute Necrotizing Encephalopathy of Childhood Secondary to Dengue Infection: A Case Report from Pakistan. J Pediatr Neurosci. 2017 Apr-Jun;12(2):165-7.

40 A-Nuegoonpipat A, Panthuyosri N, Anantapreecha S, Chanama S, Sa-Ngasang A, Sawanpanyalert P, Kurane I: Cross-reactive IgM responses in patients with dengue or Japanese encephalitis. J Clin Virol. 2008 May;42(1):757 .

41 Abbasi A, Butt N, Sheikh QH, Bhutto AR, Munir SM, Ahmed SM. Clinical features, diagnostic techniques and management of dual dengue and malaria infection. J Coll Physicians Surg Pak. 2009 Jan;19(1):25-9.

42 Barkhordarian A, Thames AD, Du AM, Jan AL, Nahcivan M, Nguyen MT, et al. Viral immune surveillance: toward a TH17/TH9 gate to the central nervous system. Bioinformation. 2015 Jan;11(1):47-54.

43 Garg RK, Rizvi I, Kumar N, Uniyal R, Malhotra HS. Case Report: Right Hemispheric Neuroimaging Abnormalities in a Patient with Dengue Encephalopathy. Am J Trop Med Hyg. 2018 Nov;99(5):1291-3. 
44 Amaral DC, Rachid MA, Vilela MC, Campos RD, Ferreira GP, Rodrigues DH, et al. Intracerebral infection with dengue-3 virus induces meningoencephalitis and behavioral changes that precede lethality in mice. J Neuroinflammation. 2011 Mar;8(1):23.

45 de Miranda AS, Rodrigues DH, Amaral DC, de Lima Campos RD, Cisalpino D, Vilela MC, et al. Dengue-3 encephalitis promotes anxiety-like behavior in mice. Behav Brain Res. 2012 Apr;230(1):237-42.

46 Hsieh MF, Lai SL, Chen JP, Sung JM, Lin YL, Wu-Hsieh BA, et al. Both CXCR3 and CXCL10/IFN-inducible protein 10 are required for resistance to primary infection by dengue virus. J Immunol. 2006 Aug;177(3): 1855-63.

47 Lin YL, Liao CL, Chen LK, Yeh CT, Liu CI, $\mathrm{Ma} \mathrm{SH}$, et al. Study of Dengue virus infection in SCID mice engrafted with human K562 cells. J Virol. 1998 Dec;72(12):9729-37.

48 Tsai TT, Chen CL, Lin YS, Chang CP, Tsai CC, Cheng YL, et al. Microglia retard dengue virus-induced acute viral encephalitis. Sci Rep. 2016 Jun;6(1):27670.

49 Valdés I, Marcos E, Suzarte E, Pérez Y, Brown E, Lazo L, et al. A dose-response study in mice of a tetravalent vaccine candidate composed of domain III-capsid proteins from dengue viruses. Arch Virol. 2017 Aug;162(8):224756.

50 Amorim JH, Pereira Bizerra RS, dos Santos Alves RP, Sbrogio-Almeida ME, Levi JE, Capurro ML, et al. A genetic and pathologic study of a DENV2 clinical isolate capable of inducing encephalitis and hematological disturbances in immunocompetent mice. PLoS One. 2012;7(9):e44984.

51 Tuiskunen A, Wahlström M, Bergström J, Buchy P, Leparc-Goffart I, Lundkvist A. Phenotypic characterization of patient dengue virus isolates in $\mathrm{BALB} / \mathrm{c}$ mice differentiates dengue fever and dengue hemorrhagic fever from dengue shock syndrome. Virol J. 2011 Aug;8(1):398.

52 Vásquez Ochoa M, García Cordero J, Gutiérrez Castañeda B, Santos Argumedo L, Villegas Sepúlveda N, Cedillo Barrón L. A clinical isolate of dengue virus and its proteins induce apoptosis in HMEC-1 cells: a possible implication in pathogenesis. Arch Virol. 2009; 154(6):919-28.

53 Tsai TT, Chen CL, Tsai CC, Lin CF. Targeting heat shock factor 1 as an antiviral strategy against dengue virus replication in vitro and in vivo. Antiviral Res. 2017 Sep;145:44-53.

54 Tseng CK, Lin CK, Wu YH, Chen YH, Chen WC, Young KC, et al. Human heme oxygenase 1 is a potential host cell factor against dengue virus replication. Sci Rep. 2016 Aug;6(1): 32176.

55 Tsetsarkin KA, Liu G, Kenney H, Bustos-Arriaga J, Hanson CT, Whitehead SS, et al. Dual miRNA targeting restricts host range and attenuates neurovirulence of flaviviruses. PLoS Pathog. 2015 Apr;11(4):e1004852.
56 Becquart P, Wauquier N, Nkoghe D, NdjoyiMbiguino A, Padilla C, Souris M, et al. Acute dengue virus 2 infection in Gabonese patients is associated with an early innate immune response, including strong interferon alpha production. BMC Infect Dis. 2010 Dec;10(1):356.

57 Navarro-Sánchez E, Desprès P, Cedillo-Barrón $\mathrm{L}$. Innate immune responses to dengue virus. Arch Med Res. 2005 Sep-Oct;36(5): 425-35.

58 Bhushan B, Sardana V, Maheshwari D, Ojha P, Mohan S, Moon P, et al. Immune-mediated neurological manifestations of dengue virusa study of clinico-investigational variability, predictors of neuraxial involvement, and outcome with the role of immunomodulation. Neurol India. 2018 Nov-Dec;66(6):1634-43.

59 Carod-Artal FJ, Wichmann O, Farrar J, Gascón J. Neurological complications of dengue virus infection. Lancet Neurol. 2013 Sep; 12(9):906-19.

60 Luo H, Winkelmann ER, Fernandez-Salas I, Li L, Mayer SV, Danis-Lozano R, et al. Zika, dengue and yellow fever viruses induce differential anti-viral immune responses in human monocytic and first trimester trophoblast cells. Antiviral Res. 2018 Mar;151:55-62.

61 Deauvieau F, Sanchez V, Balas C, Kennel A, DE Montfort A, Lang J, et al. Innate immune responses in human dendritic cells upon infection by chimeric yellow-fever dengue vaccine serotypes 1-4. Am J Trop Med Hyg. 2007 Jan;76(1):144-54.

62 Azeredo EL, De Oliveira-Pinto LM, Zagne SM, Cerqueira DI, Nogueira RM, Kubelka CF. NK cells, displaying early activation, cytotoxicity and adhesion molecules, are associated with mild dengue disease. Clin Exp Immunol. 2006 Feb;143(2):345-56.

63 Beltrán D, López-Vergès S. NK Cells during Dengue Disease and Their Recognition of Dengue Virus-Infected cells. Front Immunol. 2014 May;5:192.

64 Calvert JK, Helbig KJ, Dimasi D, Cockshell M, Beard MR, Pitson SM, et al. Dengue Virus Infection of Primary Endothelial Cells Induces Innate Immune Responses, Changes in Endothelial Cells Function and Is Restricted by Interferon-Stimulated Responses. J Interferon Cytokine Res. 2015 Aug;35(8):654-65.

65 Dalrymple NA, Mackow ER. Endothelial cells elicit immune-enhancing responses to dengue virus infection. J Virol. 2012 Jun;86(12): 6408-15.

66 Carvalho DM, Garcia FG, Terra AP, Lopes Tosta AC, Silva LA, Castellano LR, et al. Elevated dengue virus nonstructural protein 1 serum levels and altered toll-like receptor 4 expression, nitric oxide, and tumor necrosis factor alpha production in dengue hemorrhagic Fever patients. J Trop Med. 2014;2014: 901276.

67 Chang DC, Hoang LT, Mohamed Naim AN, Dong $\mathrm{H}$, Schreiber MJ, Hibberd ML, et al. Evasion of early innate immune response by 2'-O-methylation of dengue genomic RNA. Virology. 2016 Dec;499:259-66.
68 Chatel-Chaix L, Cortese M, Romero-Brey I, Bender S, Neufeldt CJ, Fischl W, et al. Dengue Virus Perturbs Mitochondrial Morphodynamics to Dampen Innate Immune Responses. Cell Host Microbe. 2016 Sep;20(3):34256.

69 Chen S, Wu Z, Wang M, Cheng A. Innate Immune Evasion Mediated by Flaviviridae NonStructural Proteins. Viruses. 2017 Oct;9(10): 9.

70 Marshall JS, King CA, McCurdy JD. Mast cell cytokine and chemokine responses to bacterial and viral infection. Curr Pharm Des. 2003;9(1):11-24.

71 Brown MG, McAlpine SM, Huang YY, Haidl ID, Al-Afif A, Marshall JS, et al. RNA sensors enable human mast cell anti-viral chemokine production and IFN-mediated protection in response to antibody-enhanced dengue virus infection. PLoS One. 2012;7(3):e34055.

72 Londono-Renteria B, Marinez-Angarita JC, Troupin A, Colpitts TM. Role of Mast Cells in Dengue Virus Pathogenesis. DNA Cell Biol. 2017 Jun;36(6):423-7.

73 Chu YT, Wan SW, Chang YC, Lee CK, WuHsieh BA, Anderson R, et al. Antibodies against nonstructural protein 1 protect mice from dengue virus-induced mast cell activation. Lab Invest. 2017 Feb;97(5):602-14.

74 Pandey S, Garg RK, Malhotra HS, Kumar N, Uniyal R. Simultaneous Occurrence of Axonal Guillain-Barré Syndrome in Two Siblings Following Dengue Infection. Ann Indian Acad Neurol. 2018 Oct-Dec;21(4):315-7.

75 Chiappelli F, Santos SM, Caldeira Brant XM, Bakhordarian A, Thames AD, Maida CA, et al. Viral immune evasion in dengue: toward evidence-based revisions of clinical practice guidelines. Bioinformation. 2014 Dec;10(12): 726-33.

76 Haltaufderhyde K, Srikiatkhachorn A, Green S, Macareo L, Park S, Kalayanarooj S, et al. Activation of Peripheral T Follicular Helper Cells During Acute Dengue Virus Infection. J Infect Dis. 2018 Oct;218(10):1675-85.

77 Jadhav NJ, Gokhale S, Seervi M, Patil PS, Alagarasu K. Immunomodulatory effect of 1, 25 dihydroxy vitamin D3 on the expression of RNA sensing pattern recognition receptor genes and cytokine response in dengue virus infected U937-DC-SIGN cells and THP-1 macrophages. Int Immunopharmacol. 2018 Sep;62:237-43.

78 Abhishek KS, Chakravarti A, Baveja CP, Kumar N, Siddiqui O, Kumar S. Association of interleukin-2, -4 and -10 with dengue severity. Indian J Pathol Microbiol. 2017 Jan-Mar; 60(1):66-9.

79 Nogueira RM, Filippis AM, Coelho JM, Sequeira PC, Schatzmayr HG, Paiva FG, et al. Dengue virus infection of the central nervous system (CNS): a case report from Brazil. Southeast Asian J Trop Med Public Health. 2002 Mar;33(1):68-71. 
80 Ab-Rahman HA, Rahim H, AbuBakar S, Wong PF. Macrophage Activation Syndrome-Associated Markers in Severe Dengue. Int J Med Sci. 2016 Feb;13(3):179-86.

81 Ab-Rahman HA, Wong PF, Rahim H, AbdJamil J, Tan KK, Sulaiman S, et al. Dengue death with evidence of hemophagocytic syndrome and dengue virus infection in the bone marrow. Springerplus. 2015 Nov;4(1):665.

82 Salomão NG, Rabelo K, Póvoa TF, Alves AM, da Costa SM, Gonçalves AJ, et al. BALB/c mice infected with DENV-2 strain 66985 by the intravenous route display injury in the central nervous system. Sci Rep. 2018 Jun; 8(1):9754.

83 Al-Shujairi WH, Clarke JN, Davies LT, Alsharifi M, Pitson SM, Carr JM. Intracranial Injection of Dengue Virus Induces Interferon Stimulated Genes and CD8+ T Cell Infiltration by Sphingosine Kinase 1 Independent Pathways.PLoSOne.2017Jan;12(1):e0169814.

84 An J, Zhou DS, Zhang JL, Morida H, Wang JL, Yasui K. Dengue-specific CD8+ T cells have both protective and pathogenic roles in dengue virus infection. Immunol Lett. 2004 Sep; 95(2):167-74.
85 Angsubhakorn S, Moe JB, Marchette NJ, Palumbo NE, Yoksan S, Bhamarapravati N. Neurovirulence effects of dengue-2 viruses on the rhesus (Macaca mulatta) brain and spinal cord. Southeast Asian J Trop Med Public Health. 1987 Mar;18(1):52-5.

86 Singh S, Maniakis-Grivas G, Singh UK, Asher RM, Mauri F, Elkington PT, et al. Interleukin-17 regulates matrix metalloproteinase activity in human pulmonary tuberculosis. J Pathol. 2018 Mar;244(3):311-22.

87 Oliveira ER, Amorim JF, Paes MV, Azevedo AS, Gonçalves AJ, Costa SM, et al. Peripheral effects induced in $\mathrm{BALB} / \mathrm{c}$ mice infected with DENV by the intracerebral route. Virology. 2016 Feb;489:95-107.

88 Soares CN, Faria LC, Peralta JM, de Freitas MR, Puccioni-Sohler M. Dengue infection: neurological manifestations and cerebrospinal fluid (CSF) analysis. J Neurol Sci. 2006 Nov;249(1):19-24.

89 Shah N, Nair AV, Ahamed S, Manoj KS. Dengue doughnut: A diagnostic magnetic resonance imaging finding in dengue encephalitis. J Postgrad Med. 2018 Apr-Jun;64(2):127.

90 Zheng Z, Yang J, Jiang X, Liu Y, Zhang X, Li $\mathrm{M}$, et al. Tick-Borne Encephalitis Virus Nonstructural Protein NS5 Induces RANTES Expression Dependent on the RNA-Dependent RNA Polymerase Activity. J Immunol. 2018 Jul;201(1):53-68.
91 Chen ST, Li FJ, Hsu TY, Liang SM, Yeh YC, Liao WY, et al. CLEC5A is a critical receptor in innate immunity against Listeria infection. Nat Commun. 2017 Aug;8(1):299.

92 Lee YR, Liu MT, Lei HY, Liu CC, Wu JM, Tung YC, et al. MCP-1, a highly expressed chemokine in dengue haemorrhagic fever/ dengue shock syndrome patients, may cause permeability change, possibly through reduced tight junctions of vascular endothelium cells. J Gen Virol. 2006 Dec;87(Pt 12): 3623-30.

93 Malavige GN, Ogg GS. Pathogenesis of vascular leak in dengue virus infection. Immunology. 2017 Jul;151(3):261-9.

94 St John AL. Influence of mast cells on dengue protective immunity and immune pathology. PLoS Pathog. 2013;9(12):e1003783.

95 Morrison J, Rathore AP, Mantri CK, Aman SA, Nishida A, St John AL. Transcriptional Profiling Confirms the Therapeutic Effects of Mast Cell Stabilization in a Dengue Disease Model. J Virol. 2017 Aug;91(18):91.

96 Velandia-Romero ML, Calderón-Peláez MA, Castellanos JE. In Vitro Infection with Dengue Virus Induces Changes in the Structure and Function of the Mouse Brain Endothelium. PLoS One. 2016 Jun;11(6):e0157786. 